\title{
Morphological and immune response alterations in the intestinal mucosa of the mouse after short periods on a low-magnesium diet
}

\author{
W. Zimowska ${ }^{1}$, J. P. Girardeau ${ }^{2}$, J. Kuryszko ${ }^{3}$, D. Bayle ${ }^{1}$, Y. Rayssiguier ${ }^{1}$ and A. Mazur ${ }^{1 *}$ \\ ${ }^{1}$ CRNH, Unité Maladies Métaboliques et Micronutriments, ${ }^{2}$ Unité Microbiologie, INRA, Theix, France \\ ${ }^{3}$ Department of Histology and Embryology, Faculty of Veterinary Medicine, Agricultural University, Wroctaw, Poland
}

(Received 8 November 2001 - Revised 6 June 2002 - Accepted 7 July 2002)

\begin{abstract}
The importance of $\mathrm{Mg}$ for the immune function is well recognized; however, there is no information available about the effect of $\mathrm{Mg}$ intake on the modulation of local immune response in the intestine. Thus, in the present study the hypothesis that short periods of $\mathrm{Mg}$ deprivation can affect intestinal mucosa and local immune response was tested. For this purpose, OF1 female mice were fed a semipurified diet $(1000 \mathrm{mg} \mathrm{Mg} / \mathrm{kg}$ diet $)$. For $3 \mathrm{~d}$ before immunization and $1 \mathrm{~d}$ after, half of the animals were fed a Mg-deficient diet ( $30 \mathrm{mg} \mathrm{Mg} / \mathrm{kg}$ diet), three immunizations per os were performed every 3 weeks with Escherichia coli producing the CS31A capsule-like protein $\left(10^{10}\right.$ or $2 \times 10^{9}$ bacteria per animal). Mice were killed $10 \mathrm{~d}$ after the last immunization. The level of specific anti CS31A immunoglobulin (Ig) G and IgA in the serum and secretory $\operatorname{IgA}$ in the intestinal secretions and faeces were measured by ELISA. The results indicated that administration of a high dose of immunogen with a low-Mg diet led to lower specific IgA levels in the intestinal mucus and serum. Administration of a low dose of immunogen with a low-Mg diet led to lower IgA and IgG levels in the serum and secretory IgA coproantibodies. To assess alterations of intestinal mucosa caused by a low-Mg diet for a short period, histological and scanning electron microscopy analyses were performed on samples from mice (not submitted to the vaccination protocol) after $3 \mathrm{~d}$ on the Mg-deficient diet. These analyses showed several alterations, suggesting perturbations in the growth of the intestinal mucosa. These changes were accompanied by modifications in the expression of several genes involved in cell growth and stress response. From this present work, it may be concluded that short periods of $\mathrm{Mg}$ deprivation can affect the intestinal mucosa and local immune response of the intestine.
\end{abstract}

Mucosal immunity: Inflammation: Magnesium deficiency: Intestine

It is generally accepted that nutrition is an important determinant of immune response (Chandra, 1997; Scrimshaw \& SanGiovanni, 1997). Nutritional deficiencies alter immunocompetence and increase the risk of infection. Several studies relating $\mathrm{Mg}$ to various aspects of immune response have been published (for reviews, see Larvor, 1980; Galland, 1988; McCoy \& Kenney, 1992). Mg is essential for the normal functioning of many components of the natural and adaptive immune defences. The detrimental effects of experimental severe $\mathrm{Mg}$ deficiency on the immune system are well known, and experimental $\mathrm{Mg}$ deficiency has been shown to affect the humoral immune system (Alcock \& Shils, 1974; McCoy \& Kenney, 1975; Elin, 1975; Rayssiguier et al. 1977; Kubena et al. 1989; Windhauser et al. 1991). Although several studies have shown impaired immunoglobulin
(Ig) $\mathrm{G}$ production, there are no results available on the relationship between $\mathrm{Mg}$ intake and local immune protection. To guard against disease, mucosal surfaces of the intestinal, respiratory and urogenital tracts are protected by a carefully regulated system of defences known as the mucosal immune system (Simecka, 1998). It is widely recognized that local mucosal immune responses, especially secretory immunoglobulin (sIg) A, play a major role in this protection (Macpherson et al. 2001). The presence of sIgA can both prevent infection of epithelial host cells and remove antigens that cross the epithelial barrier by transporting the antigen across the epithelium. There is also a tremendous benefit associated with mucosal immunization. With regard to these aspects, we have focused our present study on the mucosal and immune system responses of animals submitted to oral 
vaccination with Escherichia coli CS31A antigen during very short periods of low $\mathrm{Mg}$ intake. The small intestine mucosa histological and gene expression alterations were also assessed to learn more about changes provoked by a low-Mg diet.

\section{Materials and methods}

\section{Effect of a low-magnesium diet on the immune response after oral vaccination}

Forty female OF1 mice were purchased from IFFACREDO (L'Arblesle, France) and maintained on the standard diet until 2 months old. The mice were then adapted to a semipurified Mg-adequate diet (1000 mg $\mathrm{Mg} / \mathrm{kg}$ diet) for 2 weeks. As described later, half of the animals received a $\mathrm{Mg}$-deficient diet $(30 \mathrm{mg} \mathrm{Mg} / \mathrm{kg}$ diet $)$ $3 \mathrm{~d}$ before and $1 \mathrm{~d}$ after immunization. The experimental schedule is presented in Fig. 1(A).

For immunization, E. coli strain K12 (pEH524) producing the CS31A capsule-like protein was grown for $16 \mathrm{~h}$ in Minca medium (Guinee et al. 1976) with chloramphenicol $(25 \mu \mathrm{g} / \mathrm{ml})$. Bacterial cells were re-suspended in PBS and diluted to contain $5 \times 10^{10}$ colony-forming units $/ \mathrm{ml}$ as estimated by plating dilution. Groups of ten mice were immunized three times at 3 -week intervals by gastric intubations either with $2 \times 10^{9}$ bacterial cells (low immunogen dose) or with $10^{10}$ bacterial cells (high immunogen dose) in $300 \mu \mathrm{l} 0 \cdot 1 \mathrm{M}-\mathrm{NaHCO}_{3}$. Mice were deprived of food for $6 \mathrm{~h}$ prior to immunization.

Immunized mice were bled $10 \mathrm{~d}$ after the last immunization and sera were collected. Coproantibodies were extracted from faecal pellets as previously described (Externest et al. 2000). Briefly, after weighing, faecal pellets obtained from the rectum were vortexed and homogenized at $0^{\circ} \mathrm{C}$ for $30 \mathrm{~min}$ in $15 \mu \mathrm{l}$ cold antiprotease PBS buffer containing $50 \mathrm{~g}$ skimmed milk/l and the protease inhibitor mixture $(50 \mu \mathrm{g}$ soyabean trypsin inhibitor/ $\mathrm{ml}$, $50 \mathrm{~mm}$-EDTA, $1 \mathrm{~mm}$-phenylmethylsulfonyl fluoride)/ $\mathrm{mg}$ dry faeces. Solids were separated by centrifugation at $10000 \mathrm{~g}$ for $10 \mathrm{~min}$, the extraction was repeated twice and the extracts were combined. The faecal extract was lyophilized. Intestinal secretions were collected by a modification of the procedure described later. Briefly, the small

(A)

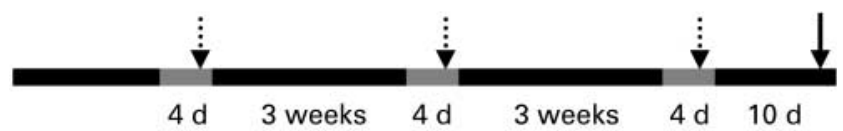

(B)

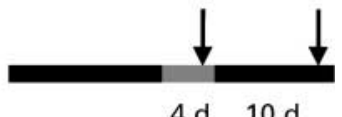

Fig. 1. Experimental schedules for the immunization and sampling protocol of mice receiving a low-magnesium diet periodically. In parallel, control mice received discontinuously the control diet. (A), oral vaccination study; (B), histological and gene expression study. For details of the diets, see p. 516. Control diet; $\square, \cdots$ immunization; $\rightarrow$, sampling. intestine was removed and $2 \mathrm{ml}$ ice-cold antiprotease PBS buffer (as described earlier) were passed through and collected. A glass tube was introduced into the small intestine and after reversion of the intestine, the intestinal secretions were scraped off and collected in ice-cold antiprotease PBS buffer. Intestinal washings and intestinal secretions were combined, vortexed and centrifuged at $3000 \mathrm{~g}$ for $20 \mathrm{~min}$ to remove cells and debris. The supernatant fractions were collected, lyophilized and weighed. The freeze-dried samples (faecal extract and intestinal washings) were reconstituted with distilled water to onefifth of the original volume and stored at $-70^{\circ} \mathrm{C}$ until assayed.

For anti-CS31A antibody titres, plates (Falcon, Becton Dickinson, Franklin Lakes, NJ, USA) were coated with $100 \mu \mathrm{l}$ CS31A-protein (chromatographically purified as previously described by Mechin et al. (1996)) $(5 \mu \mathrm{g} / \mathrm{ml})$ in carbonate buffer ( $\mathrm{pH} 9 \cdot 6)$. Wells were washed three times with PBS containing $0.5 \mathrm{ml}$ Tween 20/1, incubated overnight at $4^{\circ} \mathrm{C}$ with blocking buffer $(50 \mathrm{~g}$ dried milk powder and $5 \mathrm{ml}$ bovine serum albumin/l PBS), and washed twice with PBS-Tween buffer. Serum samples from individual mice were serially plated in twofold dilutions $(900 \mu \mathrm{l}$ per well) in antibody buffer $(10 \mathrm{ml}$ bovine serum albumin/l PBS) and incubated overnight at $4^{\circ} \mathrm{C}$. All samples were individually tested in duplicate. After washing with PBS-Tween, $100 \mu l$ peroxidaselabelled goat anti-mouse $\operatorname{IgG}$ conjugate (1:2000 dilution; Nordic Immunological Laboratories, Tilburg, The Netherlands) were added to the wells and the plates were incubated for $2 \mathrm{~h}$ at $37^{\circ} \mathrm{C}$. After washing, $100 \mu \mathrm{l} 2 \mathrm{nM}-\mathrm{H}_{2} \mathrm{O}_{2}$ and 2-2'-azino-bis(3-ethylbenzothiasoline-6-sulfonate) substrate in phosphate citrate buffer were added and plates incubated for $20 \mathrm{~min}$ in the dark at room temperature. The absorbance at $405 \mathrm{~nm}$ was read on a Dynatech MR5000 reader (Dynatech Laboratories, Inc., Guernsey, Channel Islands). Antibody titre was expressed as the $\log _{2}$ of the reciprocal of the highest dilution giving a twofold increase in optical density at $405 \mathrm{~nm}$ over that obtained with the negative control (pre-immune mouse serum). Sera, faecal extracts and intestinal washes were analysed for sIgA by a similar procedure (using peroxidase-labelled goat anti-mouse sIgA conjugate (Nordic Immunological Laboratories) as a secondary antibody) with plates coated with CS31A antigen as described earlier. Titres were adjusted in relation to a reference specimen included in each test to compensate for variations between analyses performed on different occasions. The specific sIgA antibody titres were divided by the weight of the freeze-dried extracts (faecal extracts and intestinal washings) in the sample to adjust for variations in the antibody content in specimens collected from different mice.

\section{Effect of the low-magnesium diet on the morphology and gene expression of the intestinal mucosa}

Three groups of animals without immunization were studied: the first group was fed a control diet; the second was fed the $\mathrm{Mg}$-deficient diet for $3 \mathrm{~d}$; the third group was fed the Mg-deficient diet for $4 \mathrm{~d}$ followed by $10 \mathrm{~d}$ on the control diet (eight mice per group). The experimental 
schedule is presented in Fig. 1(B). They were anaesthetized, blood was sampled into heparinized tubes by retrorbital venepuncture and the small intestine was collected for histological studies. Serum Mg was determined by flame atomic absorption spectrometric analysis (Perkin Elmer 400; Perkin Elmer, Norwalk, CT, USA).

For histological studies by optical microscopy, the pieces of small intestine were fixed with buffered formalin $(40 \mathrm{ml} / \mathrm{l})$ and embedded in paraffin. Sections $(5-7 \mu \mathrm{m}$ thick) were cut, placed on slides and stained with haematoxylin-eosin and Alcian Blue. The count of various cell types was performed on a $1 \mathrm{~mm}^{2}$ area.

Villi morphology was studied by scanning electron microscopy after $3 \mathrm{~d}$ on the $\mathrm{Mg}$-deficient diet. The pieces ( $1.5 \mathrm{~cm}$ length) of small intestine were fixed with absolute alcohol-formalin (100 ml/l)-acetic acid (6:3:1, by vol.). The samples were dehydrated four-fold with butanol for $24 \mathrm{~h}$, impregnated in Parawax at $60^{\circ} \mathrm{C}$, cut $(5-7 \mu \mathrm{m}$ thick), placed on the slides and observed in a Philips 505 scanning electron microscope (Philips, Eindhoven, Holland).

The mucosa scraped off the small intestine and total RNA extraction was performed immediately according to Chomczynski \& Sacchi (1987). Contaminating DNA was removed by incubation with $200 \mathrm{U}$ DNase I, RNase-free (Roche, Meylan, France). Quantification and purity of the RNA was assessed by absorption at $260 \mathrm{~nm}$ :absorption at $280 \mathrm{~nm}$; RNA samples with ratios $>1.6$ were stored at $-70^{\circ} \mathrm{C}$ for further analysis.

To generate radiolabelled cDNA probes for cDNA array, pooled $5 \mu \mathrm{g}$ total RNA for each group (control and $3 \mathrm{~d}$ on the Mg-deficient diet (eight mice per group)) was synthesized with Moloney-murine-leukaemia virus reverse transcriptase and $2 \mu \mathrm{l}$ cDNA synthesis Primer Mix (Clontech, Palo Alto, CA, USA). Each cDNA reaction was conducted in a volume of $22 \mu \mathrm{l}$ containing $2.63 \mathrm{~Bq}$ deoxyadenosine $5^{\prime}-\left[\alpha-{ }^{32} \mathrm{P}\right]$ triphosphate. The radiolabelled cDNA probes were purified from unincorporated nucleotides by gel filtration using Chroma-Spin-200 columns (Clontech) and hybridized overnight at $68^{\circ} \mathrm{C}$ to a rat cDNA expression array membranes consisting of 1176 known genes (Atlas ${ }^{\mathrm{TM}}$ Mouse 1.2 Array; Clontech) as described by the manufacturer. The hybridization data were collected with a Molecular Dynamics PhosphorImager $^{\mathrm{TM}}$ (Molecular Dynamics, Sunnyvale, CA, USA) and analysed as specified by the array manufacturer. A complete list of genes on the array is available (BD

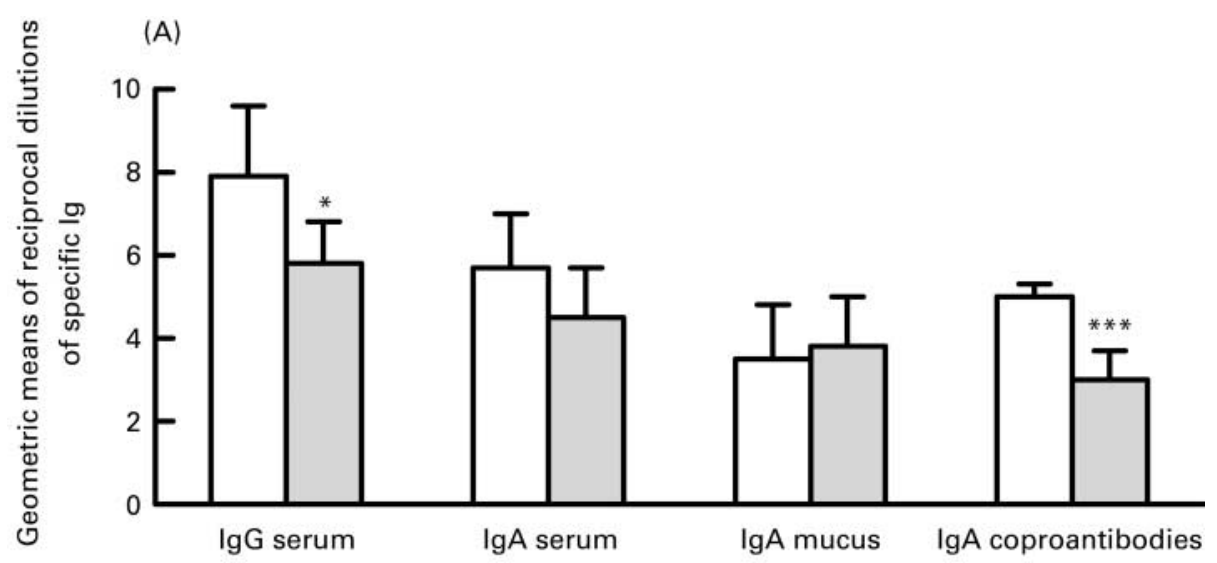

(B)

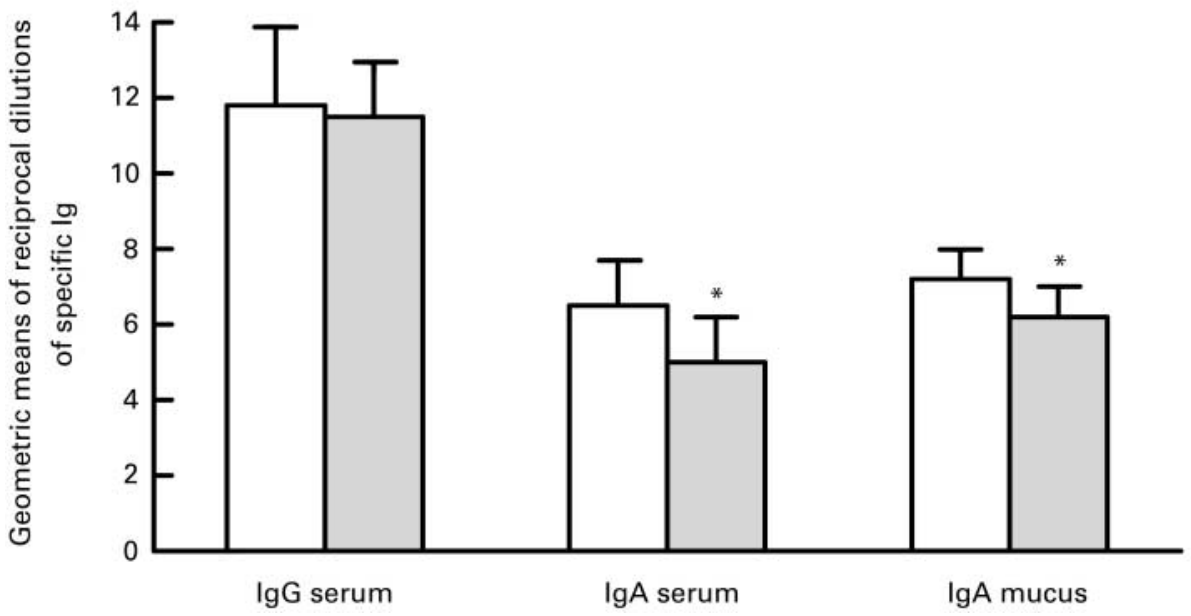

Fig. 2. The influence of (A), low and (B), high antigen dose on the level (titre $\log _{2}$ ) of specific anti-CS31A immunoglobulin (Ig) $A$ and antiCS31A IgG in the serum and anti-CS31A IgA in the intestinal mucosa. $\square$, Control; $\square$, low-magnesium diet. For details of diets and procedures, see Fig. 1 and p. 516. Values are means for ten mice per group with standard deviations shown by vertical bars. Mean values were significantly different from those of the control group: ${ }^{\star} P<0.05 ;{ }^{* \star \star} P<0.001$. 
BioSciences, 2002) The AtlasImage (Clontech) software was used to compare gene expression profiles between the two groups studied. Signal intensities between the compared arrays were normalized using the Global Mode (to develop a normalization coefficient), which uses an average value based on all the expressed genes. Analysis was conducted after $72 \mathrm{~h}$ screen exposure. The hybridization procedure represents a single array experiment. The changes in gene expression of selected genes were confirmed by reverse transcription-polymerase chain reaction (PCR). For this purpose, $3 \mu \mathrm{g}$ total RNA converted into first strand cDNA using Ready-To-Go You-Prime FirstStrand Beads Kit (Amersham Pharmacia Biotech Inc, Piscataway, NJ, USA) and $1 \mu \mathrm{l}(0.5 \mathrm{mg} / \mathrm{ml})$ oligo (dT) Primer (Promega, Madison, WI, USA) were incubated at $37^{\circ} \mathrm{C}$ for $60 \mathrm{~min}$. The PCR was performed in a fluorescence temperature cycler (LightCycler; Roche Diagnostics $\mathrm{GmbH}$, Mannheim, Germany). Amplification was performed in a $20 \mu \mathrm{l}$ final reaction volume containing $2 \mu \mathrm{l}$ LC-FastStart DNA Master SYBR Green I (FastStart Taq DNA (Roche Diagnostics GmbH), reaction buffer, dNTP mix with dUTP instead of dTTP, SYBR Green I dye (Roche Diagnostics $\mathrm{GmbH}$ )), $1.6 \mu \mathrm{l} 3 \mathrm{~mm}-\mathrm{MgCl}_{2}, 2 \mu \mathrm{l}$ $0.4 \mu \mathrm{m}$ each specific primer (Isoprim, Toulouse, France), $7.4 \mu \mathrm{l} \mathrm{H}_{2} \mathrm{O}$ (sterile PCR grade; Roche Diagnostics $\mathrm{GmbH})$ and $5 \mu \mathrm{l}$ cDNA template (1:100). For the PCR step, the following specific primers were used: mouse cytokeratin 19 (CK19): product size $125 \mathrm{bp}$, forward 5' ACT ACA ACA ATC TGC CCA CC $3^{\prime}$ and reverse GGA TAG TTT TAT TGA CAA GTC GAG G 3'; mouse plasma glutathione peroxidase-3 product size $166 \mathrm{bp}$, forward GAA CTG AAT GCA CTA CAA GAA GAA C

(A)

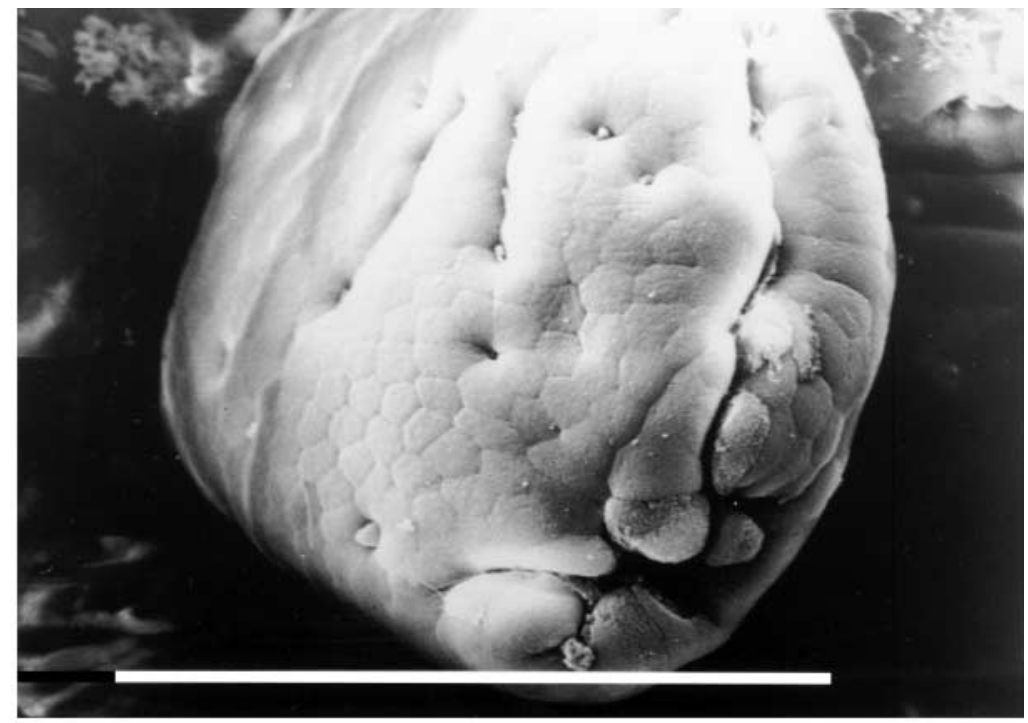

(B)

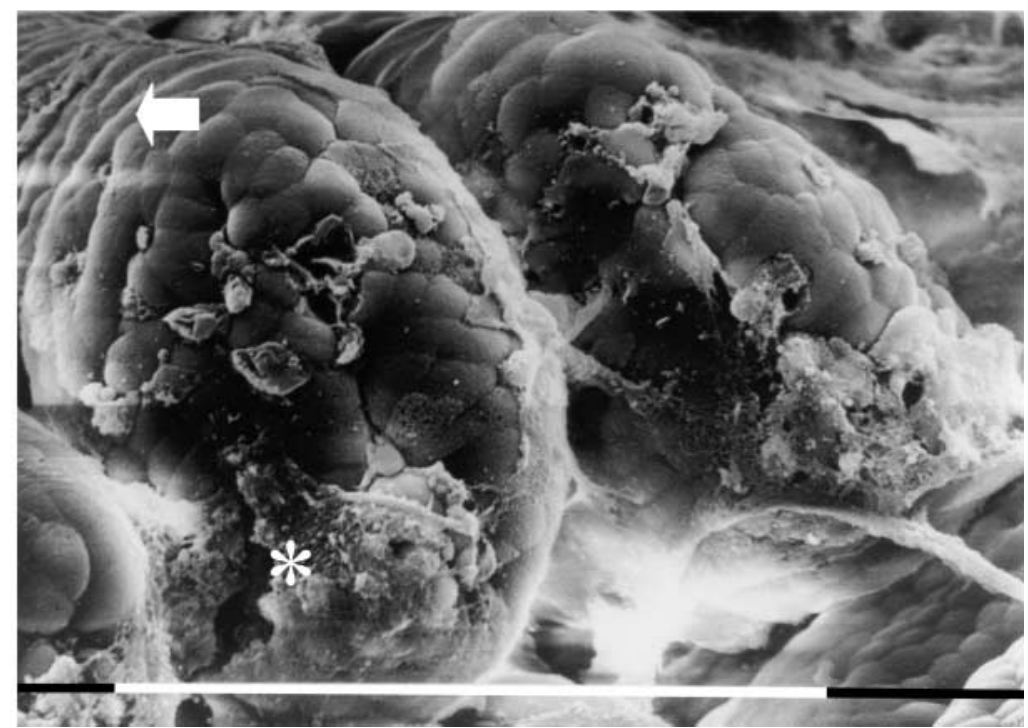

Fig. 3. Changes in the villi of mouse small intestine after $3 \mathrm{~d}$ on low-magnesium diet as observed by scanning electron microscopy. (A), control; (B), low-magnesium diet. The scale bar represents $100 \mu \mathrm{m}$. $\Leftarrow$, Intestinal villi from deficient mice were more flattened; *, the grooves were observed on the top of villi and contained more exfoliating cells. For details of diets and procedures, see Fig. 1 and p. 516. 
$3^{\prime}$ and reverse $5^{\prime}$ CAA AGA GCT GGA AAT TAG GCA C $3^{\prime}$. For normalization a mouse cytoplasmic $\beta$-actin product size 104, forward 5' TGT GGA TCA GCA AGC AGG AG $3^{\prime}$ and reverse 5' CAA AGA AAG GGT GTA AAA CGC AG $3^{\prime}$ was used. The amplification programme included the initial denaturation step at $95^{\circ} \mathrm{C}$ for $480 \mathrm{~s}$ and fortyfive cycles of denaturation at $95^{\circ} \mathrm{C}$ for $10 \mathrm{~s}$, annealing at $60^{\circ} \mathrm{C}$ for $10 \mathrm{~s}$ and extension at $72^{\circ} \mathrm{C}$ for $10 \mathrm{~s}$. The temperature transition rate was $20^{\circ} \mathrm{C} / \mathrm{s}$. Fluorescence was measured at the end of each step. After amplification, a melting curve was acquired by heating the product at $20^{\circ} \mathrm{C} / \mathrm{s}$ to $95^{\circ} \mathrm{C}$, cooling it at $20^{\circ} \mathrm{C} / \mathrm{s}$ to $72^{\circ} \mathrm{C}$, keeping it at $72^{\circ} \mathrm{C}$ for $30 \mathrm{~s}$, and slowly heating it at $0 \cdot 1{ }^{\circ} \mathrm{C} / \mathrm{s}$ to $95^{\circ} \mathrm{C}$. Melting curves were used to determine the specificity of the PCR.

\section{Statistical analysis}

Results for each test group are expressed as the mean values (or mean values of $\log _{2}$ titres) and standard deviations. Levels of significance of the difference between groups were determined by the Students $t$ test or oneway ANOVA with post-hoc test (Student-Newman-Keuls).

\section{Results}

Effect of the low-magnesium diet on the immune response after oral vaccination

No differences were observed among all groups studied in both body weight and serum $\mathrm{Mg}$ at the end of the experimental period in both experiments with low and high immunogen immunization (results not shown). Low immunogen vaccination during the low-Mg diet led to an approximately four-fold decrease in coproantibodies $\operatorname{sig} \mathrm{A}$ and serum $\operatorname{IgA}$ and $\operatorname{IgG}$ antibodies levels (Fig. 2(A)). High immunogen vaccination resulted in a four-fold increase in $\operatorname{IgA}$ antibody level in the sera and in the intestinal washing fluids in control diet-fed mice (Fig. 2(B)). However, a low-Mg diet during immunization led to a twofold decrease of intestinal $\operatorname{sgA}$ and serum $\operatorname{IgA}$ levels compared with the respective control group (Fig. 2(B)).

\section{Effect of the low-magnesium diet on the morphology and gene expression of the intestinal mucosa}

The small intestine mucosa histological and gene expression alterations were also assessed to learn more about changes provoked by low-Mg diet. For this purpose, a similar feeding protocol was used on non-vaccinated mice as on vaccinated mice, i.e. $3 \mathrm{~d}$ on the $\mathrm{Mg}$-deficient diet or $4 \mathrm{~d}$ on the $\mathrm{Mg}$-deficient diet and then return to the control diet for $10 \mathrm{~d}$. The results were compared with control diet-fed mice. Plasma Mg concentration was decreased by about one-half in animals that received $\mathrm{Mg}$-deficient diet for $3 \mathrm{~d}$ compared with those fed $\mathrm{Mg}$-adequate diet (0.45 (SD 0.06) v. 0.87 (SD 0.08) $\mathrm{mm}$ respectively, eight per group, $P<0.001)$ and were restored in $\mathrm{Mg}$-deficient mice after $10 \mathrm{~d}$ on the control diet $(0.86$ (SD 0.07)). The

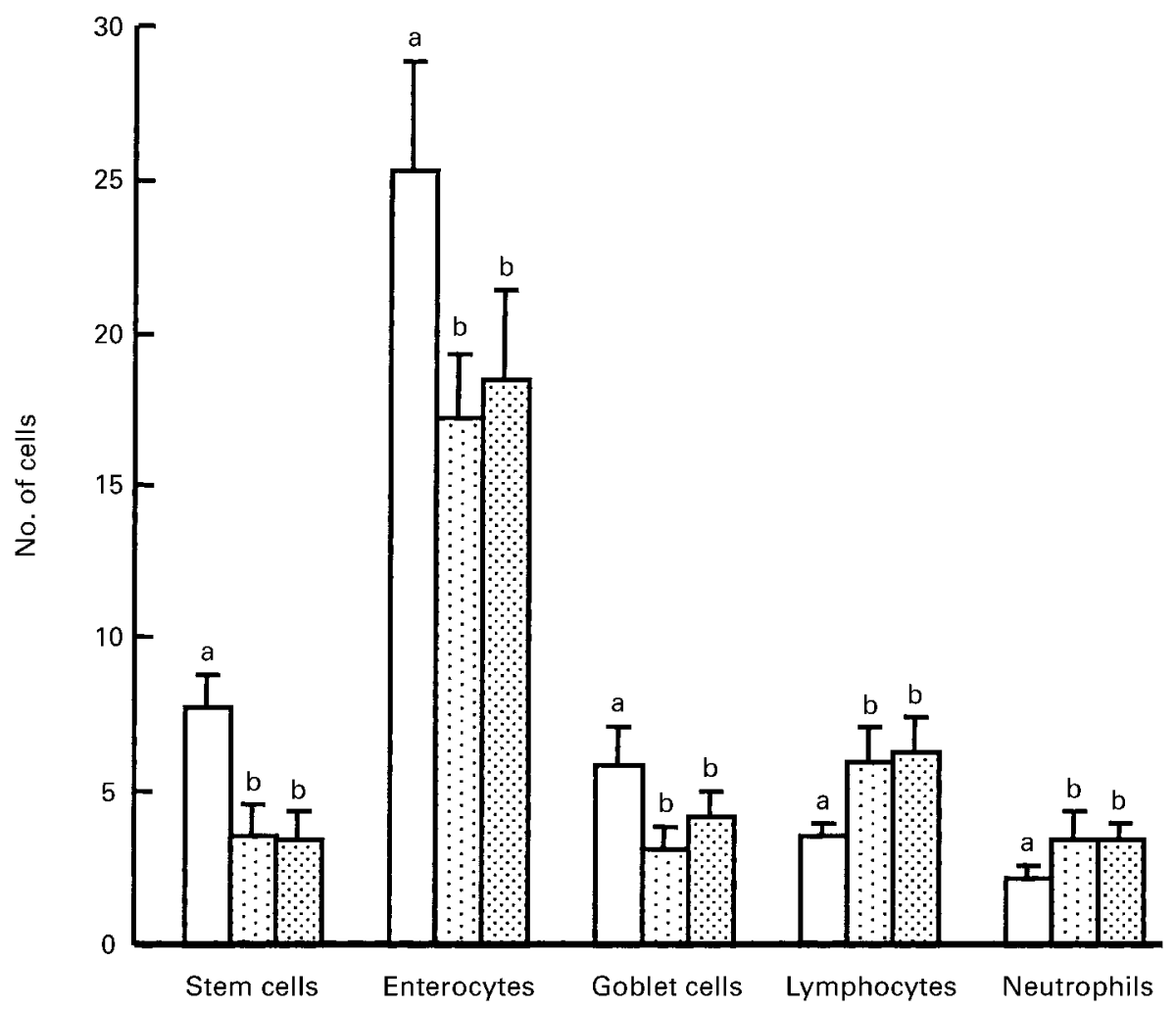

Fig. 4. Histological alterations of intestinal mucosa caused by a low-magnesium diet. $\square$, Control; 围, low-magnesium diet for $3 \mathrm{~d}$; 圆, low-magnesium diet for $4 \mathrm{~d}$ and then control diet for $10 \mathrm{~d}$. The number of cells was calculated on the $100 \mu \mathrm{m}$ from the bottom of the glands of the intestine. For details of diets and procedures, see Fig. 1 and p. 516. Values are means for six mice per group with standard deviations shown by vertical bars. ${ }^{a, b}$ Mean values with unlike superscript letters were significantly different; $(P<0.05)$. 
level of tumour necrosis factor- $\alpha$ was below the detection limits in all groups studied and interleukin 6 concentrations were not modified by dietary treatments (after $3 \mathrm{~d}$ on Mg-deficient diet 56 (SD 23), after return to the control diet 68 (SD 27) $v$. controls 70 (SD 28) $\mathrm{pg} / \mathrm{ml}$, eight per group).

Scanning electron microscopy pictures of intestinal mucosa from animals fed a Mg-deficient diet for $3 \mathrm{~d}$ and controls are presented in Fig. 3. Intestinal villi from deficient mice were considerably more flattened, the grooves were observed on the top of villi and contained more exfoliating cells.

Histological analysis performed by optical microscopy also confirmed the alteration in growth of intestinal mucosa caused by $3 \mathrm{~d}$ on low-Mg diet (Fig. 4). A decreased number of stem cells, enterocytes and goblet cells were observed; however, there was an increase in the number of white cells (lymphocytes and neutrophils). These histological alterations were still present $10 \mathrm{~d}$ after returning to the control diet.

Table 1. Differential gene expression evaluated by cDNA array in intestinal mucosa of mice after $3 \mathrm{~d}$ on a low-magnesium diet ${ }^{\star}$

\begin{tabular}{|c|c|c|}
\hline Ratio† & Gene description & Gene bank \\
\hline & Up regulated & \\
\hline $4 \cdot 6$ & Cyclin G2 (G2/M-specific) & U95826 \\
\hline 3.9 & c-Src proto-oncogene & M17031 \\
\hline 3.5 & $\begin{array}{l}\text { Epidermal growth factor receptor } \\
\text { kinase substrate EPS8 }\end{array}$ & L21671 \\
\hline 3.5 & $\begin{array}{l}\text { Sodium-dependent 5-hydroxytrytamine } \\
\text { transporter; 5-hydroxytrytamine } \\
\text { transporter }\end{array}$ & AF013604 \\
\hline $3 \cdot 3$ & Glucose regulated protein 78 & D78645 \\
\hline $3 \cdot 3$ & G2/M-specific cyclin G & Z37110 \\
\hline $3 \cdot 2$ & $\begin{array}{l}\text { Tumour necrosis factor receptor family } \\
\text { member-associated }\end{array}$ & U51907 \\
\hline $3 \cdot 2$ & Integrin $\alpha 6$ & X69902 \\
\hline $3 \cdot 1$ & Caudal type homeobox 2 & S74520 \\
\hline 2.5 & $\begin{array}{l}\text { Ezrin; villin 2; neurofibromatosis-2 } \\
\text { (merlin) related filament/plasma } \\
\text { membrane associated protein }\end{array}$ & $\mathrm{X} 60671$ \\
\hline $2 \cdot 4$ & c-fos proto-oncogene; p55 & V00727 \\
\hline 2.4 & A-Raf proto-oncogene & M13071 \\
\hline $2 \cdot 3$ & G1/S-specific cyclin D1 & S78355 \\
\hline $2 \cdot 2$ & $\begin{array}{l}\text { Signal transducer and activator of } \\
\text { transcription } 6 \text {; interleukin } 4 \text { signal } \\
\text { transducer and activator of } \\
\text { transcription }\end{array}$ & L47650 \\
\hline $2 \cdot 2$ & $\begin{array}{l}\text { Integrin } \alpha 3 \text { precursor galactoprotein B3; } \\
\text { very late antigen-3 } \alpha \text { subunit }\end{array}$ & D13867 \\
\hline $2 \cdot 2$ & Occludin & U49185 \\
\hline $2 \cdot 1$ & $\begin{array}{l}\text { Transcription factor } \mathrm{AP}-1 ; \mathrm{c}-\mathrm{jun} \\
\text { proto-oncogene; } \mathrm{AH} 119\end{array}$ & J04115 \\
\hline $2 \cdot 1$ & $\begin{array}{l}\text { Transcription factor S-II; transcription } \\
\text { elongation factor }\end{array}$ & D00926 \\
\hline $2 \cdot 1$ & $\begin{array}{l}\text { Plasma glutathione peroxidase precursor } \\
\text { glutathione peroxidase } 3\end{array}$ & U13705 \\
\hline $2 \cdot 1$ & $\begin{array}{l}\text { Tob antiproliferative factor; interacts } \\
\text { with p185erbB2 } \\
\text { Down regulated }\end{array}$ & D78382 \\
\hline 0.4 & $\begin{array}{l}\text { Type I cytoskeletal keratin 19; } \\
\text { cytokeratin } 19\end{array}$ & M28698 \\
\hline 0.1 & Transcription termination factor 1 & X83974 \\
\hline
\end{tabular}

${ }^{*}$ For details of diets and procedures, see p. 516 .

† Low-Mg:control.
To learn more about the molecular mechanisms that mediate the effects of low-Mg intake on the intestinal mucosa, the modulation of gene expression by means of cDNA array analysis was studied in mice receiving a Mg-deficient diet for $3 \mathrm{~d}$. Mg deficiency for $3 \mathrm{~d}$ resulted in significant changes of gene expression in intestinal mucosa in comparison with control diet-fed mice. The most prominent changes (more than two-fold modification) are listed in Table 1. For example, the up regulated genes included cyclin G2, glucose regulated protein 78, tumour necrosis factor receptor-associated nuclear factor $\mathrm{\kappa}-\mathrm{B}$ activator and plasma glutathione peroxidase 3 . The down regulated genes included cytokeratin 19 and transcription termination factor 1. Quantitative reverse transcriptionPCR for selected genes confirmed the results obtained from cDNA array $(\mathrm{Mg}$ deficient:control ratio values: glutathione peroxidase 32.0 (SD 0.4) (n 2), cytokeratin $190.6(\mathrm{SD} 0 \cdot 3)(n$ 6)). There were no perceptible differences in the expressions of interleukin $1,6,10$ or 12 and tumour necrosis factor- $\alpha$ in the mucosa of the low Mg-diet group compared with controls, which were tested by multiple PCR (results not shown).

\section{Discussion}

Specific sIgA antibodies serve to protect the mucosal surface from diseases by inhibiting bacterial adherence to epithelial cells and by neutralizing toxins. In the present study, we addressed the question of whether $\mathrm{Mg}$ intake can modulate systemic and local immune responses against bacterial antigens after oral administration. For this purpose we have used E. coli CS31A surface antigen, which is a potent mucosal immunogen, inducing high secretory as well as systemic antibody responses upon oral administration (Der Vartanian et al. 1997). Here, we have shown the deleterious effects of low-Mg diet on the mouse systemic and local mucosal immune responses to this immunogen. A low-Mg diet also gives rise to several morphological and histological alterations of the intestinal mucosa after a few days. The decreased number of villi cells, indicating a reduced villi growth, and an increased number of lymphocytes and neutrophils in the intestinal mucosa were shown. This latter observation confirms inflammatory response described in $\mathrm{Mg}$-deficient rodents (for review, see Rayssiguier et al. 2001). Thus, these inflammatory phenomena also concerned the gastrointestinal tract as has been previously described in the stomach and duodenum of Mg-deficient rats (Artizzu \& Messier, 1971; Kraeuter \& Schwartz, 1980). Interestingly histological alterations were still present even after $10 \mathrm{~d}$ return to the control diet.

The results presented here showed clearly the alterations in the growth of intestinal mucosa and inflammation caused by Mg-deficient diet. To learn more about the molecular mechanisms that mediate the effects of low $\mathrm{Mg}$ intake on the intestinal mucosa the modulation of gene expression was studied by means of cDNA array analysis. After $3 \mathrm{~d}$ on $\mathrm{Mg}$-deficient diet significant changes were found in the expression of several genes involved in cell cycle and stress response, for example the up regulation of cyclin $\mathrm{G} 2$, glucose regulated protein 78 , tumour 
necrosis factor receptor-associated nuclear factor $\kappa-B$ activator, glutathione peroxidase 3 and down regulation of cytokeratin-19 and trancription terminator factor 1 . Inflammatory response has been proposed to be responsible for oxidative damage in $\mathrm{Mg}$-deficient rodents (Rayssiguier et al. 2001). This could explain an increase in the expression of glutathione peroxidase 3 , an antioxidant enzyme. The up regulation of stress response genes, for example, glucose regulated protein 78 , could be related to the defence against cell damage (Petrault et al. 2002) and that of tumour necrosis factor receptor-associated nuclear factor $\kappa-B$ activator to the suppression of cell death by tumour necrosis factor (Chin et al. 1999). The up regulation of cyclin $\mathrm{G} 2$, which is known to be a negative regulator of cell cycle progression (Horne et al. 1997), and the down regulation of cytokeratin-19, which is associated with low cell proliferation and differentiation (Stammberger \& Baczako, 1999), were also found. However, modifications in the plasma level of proinflammatory cytokines (tumour necrosis factor $\alpha$ and interleukin 6) and in the cytokine gene expression in the mucosa of mice after $3 \mathrm{~d}$ on the deficient diet were not observed. It could be hypothesized that $3 \mathrm{~d}$ on the deficient diet is too short a period to induce perceptible modifications in proinflammatory cytokines in the plasma and tissues. However, this does not exclude the possible role of inflammatory cells, which can contribute as the source of locally effective cytokines. In fact, previous studies have shown the presence of elevated levels of proinflammatory cytokines in $\mathrm{Mg}$-deficient rodents after only a few days on the $\mathrm{Mg}$ deficient diet (Weglicki et al. 1992; Malpuech-Brugère et al. 2000). It has also been shown that rats are more sensitive to immune stress after $2 \mathrm{~d}$ on a $\mathrm{Mg}$-deficient diet (Malpuech-Brugère et al. 1998, 1999) and that these animals show alterations of several immune cells (macrophages, neutrophils and thymocytes) (Kurantsin-Mills et al. 1997; Malpuech-Brugère et al. 2000; Bussière et al. 2002; Petrault et al. 2002). These modifications occur before inflammatory symptoms and point out the early events affecting the immune system in $\mathrm{Mg}$ deficiency. The effect of $\mathrm{Mg}$ on cell growth is well known and it was demonstrated that $\mathrm{Mg}$ deprivation inhibits DNA and protein synthesis thus promoting growth arrest (Wolf et al. 2001). This could explain both reduced cell proliferation of the villi and reduced Ig synthesis.

Collectively, the present study and previously published observations stress the importance of $\mathrm{Mg}$ for optimal immune function. This could be of great importance because even if isolated $\mathrm{Mg}$ deficiency in man is rare, malnutrition is usually a composite of multiple nutrient deficiencies including $\mathrm{Mg}$. Recent epidemiological results also indicate low $\mathrm{Mg}$ intake in populations of developed countries (Galan et al. 1997). In addition, $\mathrm{Mg}$ deficit is frequently associated with several physiopathological conditions (such as diabetes, alcoholism, exercise) (Durlach, 1988) and low Mg intake can occasionally occur in specific populations (elderly, hospitalized patients).

In conclusion, the present study demonstrates that $\mathrm{Mg}$ deprivation, even for only a few days, can affect intestinal mucosa and the local immune response of the intestine. This points out the essential role that $\mathrm{Mg}$ plays in the integrity and defence of the gastrointestinal tract. Further questions should be addressed on the role of $\mathrm{Mg}$ in cell cycle dynamics, that could thence affect gut integrity, and on the role of inflammatory phenomena occurring in $\mathrm{Mg}$ deficiency in the observed depressed specific response.

\section{Acknowledgement}

We thank Mrs Brigitte Gaillard-Martinie for scanning electron microscope analysis.

\section{References}

Alcock NW \& Shils ME (1974) Serum immunoglobulin G in the magnesium-depleted rat. Proceedings of the Society for Experimental Biology and Medicine 145, 855-858.

Artizzu M \& Messier B (1971) Histological changes in the gastric mucosa of magnesium deficient rats. British Journal of Experimental Pathology 52, 70-74.

BD Biosciences (2002) Atlas ${ }^{\mathrm{TM}}$ Arrays and Gene Lists. Atlas mouse 1.2 array cat. no. 78531. http:/clontech.com/atlas/ genelists/7853-1_Mo12.txt

Bussière FI, Gueux E, Rock E, Girardeau J-P, Tridon A, Mazur A \& Rayssiguier Y (2002) Increased phagocytosis and production of reactive oxygen species of neutrophils during magnesium deficiency in rats and inhibition by high magnesium concentration. British Journal of Nutrition 87, 107-113.

Chandra RK (1997) Nutrition and the immune system: an introduction. American Journal of Clinical Nutrition 66, $460 \mathrm{~S}-463 \mathrm{~S}$

Chin AI-D, Shu J, Shi CS, Yao Z, Kehrl JH \& Cheng G (1999) TANK potentiates tumor necrosis factor receptor-associated factor-mediated c-Jun N-terminal kinase/stress-activated protein kinase activation through the germinal center kinase pathway. Molecular and Cellular Biology 19, 6665-6672.

Chomczynski P \& Sacchi N (1987) Single-step method of RNA isolation by acid guanidium thiocyanate-phenol-chloroform extraction. Analytical Biochemistry 162, 156-159.

Der Vartanian M, Girardeau JP, Martin C, Rousset E, Chavarot M, Laude H \& Contrepois M (1997) An Escherichia coli CS31A fibrillum chimera capable of inducing memory antibodies in outbred mice following booster immunization with the entero-pathogenic coronavirus transmissible gastroenteritis virus. Vaccine 15, 111-120.

Durlach J (1988) Magnesium in Clinical Practice [J Durlach, editor]. London: John Libbey.

Elin RJ (1975) The effect of magnesium deficiency in mice on serum immunoglobulin concentrations and antibody plaqueforming cells. Proceedings of the Society for Experimental Biology and Medicine 148, 620-624.

Externest D, Meckelein B, Schmidt MA \& Frey A (2000) Correlations between antibody immune responses at different mucosal effector sites are controlled by antigen type and dosage. Infection and Immunity 68, 3830-3839.

Galan P, Preziosi P, Durlach V, Valeix P, Ribas L, Bouzid D, Favier A \& Hercberg S (1997) Dietary magnesium intake in a French adult population. Magnesium Research 10, 321-328.

Galland L (1988) Magnesium and immune function: an overview. Magnesium 7, 290-299.

Guinee PA, Jansen WH \& Agterberg CM (1976) Detection of the K99 antigen by means of agglutination and immunoelectrophoresis in Escherichia coli isolates from calves and its correlation with entertoxigenicity. Infection and Immunity 13, 1369-1377. 
Horne MC, Donaldson KL, Goolsby GL, Tran D, Mulheisen M, Hell JW \& Wahl AF (1997) Cyclin G2 is up-regulated during growth inhibition and $\mathrm{B}$ cell antigen receptor-mediated cell cycle arrest. Journal of Biological Chemistry 272, $12650-12661$.

Kraeuter SL \& Schwartz R (1980) Blood and mast cell histamine levels in magnesium-deficient rats. Journal of Nutrition 110, $851-858$.

Kubena KS, Cohill DT \& McMurray DN (1989) Effect of varying levels of magnesium during gestation and lactation on humoral immune response and tissue minerals in rats. Annals of Nutrition and Metabolism 33, 7-14.

Kurantsin-Mills BJ, Cassidy MM, Stafford RE \& Weglicki WB (1997) Marked alterations in circulating inflammatory cells during cardiomyopathy development in a magnesium-deficient rat model. British Journal of Nutrition 78, 845-855.

Larvor P (1980) Magnesium, humoral immunity, and allergy. In Magnesium in Health and Disease Proceedings of the 2nd International Symposium on Magnesium, pp. 201-224 [M Cantin and MS Seelig, editors]. New York: SP Medical and Scientific Books.

McCoy JH \& Kenney MA (1975) Depressed immune response in the magnesium-deficient rat. Journal of Nutrition 105, 791-797.

McCoy JH \& Kenney MA (1992) Magnesium and immune function: recent findings. Magnesium Research 5, 281-293.

Macpherson AJ, Hunziker L, McCoy K \& Lamarre A (2001) IgA responses in the intestinal mucosa against pathogenic and non-pathogenic microorganisms. Microbes in Infections 3, $1021-1035$.

Malpuech-Brugère C, Nowacki W, Daveau M, Gueux E, Linard C, Rock E, Lebreton J-P, Mazur A \& Rayssiguier Y (2000) Inflammatory response following acute magnesium deficiency in the rat. Biochimica et Biophysica Acta 1501, 91-98.

Malpuech-Brugère C, Nowacki W, Rock E, Gueux E, Mazur A \& Rayssiguier Y (1999) Enhanced tumor necrosis factor- $\alpha$ production following endotoxin challenge in rats is an early event during magnesium deficiency. Biochimica et Biophysica Acta 1453, 35-40.

Malpuech-Brugère C, Rock E, Astier C, Nowacki W, Mazur A \& Rayssiguier Y (1998) Exacerbated immune stress response during experimental magnesium deficiency results from abnormal cell calcium homeostasis. Life Sciences 63, $1815-1822$.
Mechin MC, Rousset E \& Girardeau JP (1996) Identification of surface-exposed linear B-cell epitopes of the nomfimbrial adhesin CS31A of Escherichia coli by using overlapping peptides and antipeptide antibodies. Infection and Immunity 64, 3555-3564.

Petrault I, Zimowska W, Mathieu J, Bayle D, Rock E, Favier A, Rayssiguier Y \& Mazur A (2002) Changes in gene expression in rat thymocytes identified by cDNA array support the occurrence of oxidative stress in early magnesium deficiency. Biochimica et Biophysica Acta 1586, 92-98.

Rayssiguier Y, Bussiere F, Gueux E, Rock E \& Mazur A (2001) Acute phase response in magnesium deficiency: possible relevance to atherosclerosis. In Advances in Magnesium Research: Nutrition and Health, pp. 277-283 [Y Rayssiguier, A Mazur and J Durlach, editors]. London: John Libbey.

Rayssiguier Y, Larvor P, Augusti Y \& Durlach Y (1977) Rat serum proteins during magnesium deficiency. Annales de Biologie Animale Biochimie Biophysique 17, 147-152.

Scrimshaw NS \& SanGiovanni JP (1997) Synergism of nutrition, infection, and immunity: an overview. American Journal of Clinical Nutrition 66, 464S-477S.

Simecka JW (1998) Mucosal immunity of the gastrointestinal tract and oral tolerance. Advanced Drug Delivery Reviews 34, $235-259$.

Stammberger P \& Baczako K (1999) Cytokeratin 19 expression in human gastrointestinal mucosa during human prenatal development and in gastrointestinal tumours: relation to cell proliferation. Cell and Tissue Research 298, 377-381.

Weglicki WB, Phillips TM, Freedman AM, Cassidy MM \& Dickens BF (1992) Magnesium-deficiency elevates circulating levels of inflammatory cytokines and endothelin. Molecular and Cellular Biochemistry 110, 169-173.

Windhauser MM, Kappel LC \& Hegsted M (1991) The humoral immune response in marginally and severely magnesium deficient rats. Journal of Nutritional Biochemistry 2, $541-546$.

Wolf FI, Sgambato A, Covacci V, Faraglia B, Torsello A, Ardito R \& Cittadini A (2001) Magnesium in the control cell of proliferation: a metabolic enhancer or a specific regulator? In Advances in Magnesium Research: Nutrition and Health, pp. 73-81 [Y Rayssiguier, A Mazur and J Durlach, editors]. London: John Libbey. 